\title{
Potassium bicarbonate and D-ribose effects on A72 canine and HTB-126 human cancer cell line proliferation in vitro
}

\author{
Simonetta Croci ${ }^{1,2^{*}}$, Luca Bruni ${ }^{1,2,3}$, Simona Bussolati ${ }^{4}$, Marianna Castaldo ${ }^{2}$ and Maurizio Dondi ${ }^{5}$
}

\begin{abstract}
Background: The synergic action of $\mathrm{KHCO}_{3}$ and D-ribose is tested on A72 and HTB-126 cell lines proliferation using K:D-Rib solution. Altered $\mathrm{Na}^{+} / \mathrm{K}^{+}$ATPase expression and activity were shown in patients with cancer. Studies in human epithelial-derived malignancies indicate that $\mathrm{K}^{+}$depletion also occurs, contributing to the increased intracellular $\mathrm{Na}^{+} / \mathrm{K}^{+}$ratio [1]. D-ribose transformed to piruvate, enters into the Krebs's cycle and has a key role on energetic metabolism. The up-regulation of glycolysis in tumor cells is already well known and it is the rationale of $F^{18}$-FDG PET diagnostic technique. D-ribose is synthesized by the non-oxidative transketolase PPP reaction.

Results: Results with different K:D-Rib concentrations show that MTT salt interferes with K:D-Rib solution and therefore this method is not reliable. The UVNIS measurements show that K:D-Rib solutions reduce MTT salt to formazan in absence of cells. Cell proliferation has then been evaluated analysing the digital photos of the Giemsa stained cells with MCIDTM software. At 5 mM K:D-Rib concentration, the cell growth arrests between $48 \mathrm{~h}$ and $72 \mathrm{~h}$; in fact the cell number after $48 \mathrm{~h}$ is around the same with respect to the control after $72 \mathrm{~h}$. In case of HTB-126 human cancer cells, the growth rate was valuated counting the splitting times during 48 days: control cells were split sixteen times while $5 \mathrm{mM}$ treated cells eleven times. Most relevant, the clonogenic assay shows that nine colonies are formed in the control cells while only one is formed in the $5 \mathrm{mM}$ and none in $10 \mathrm{mM}$ treated cells.

Conclusions: The K:D-Rib solution has an antioxidant behaviour also at low concentrations. Incubation with $5 \mathrm{mM}$ K:D-Rib solution on A72 cells shows a cytostatic effect at $5 \mathrm{mM}$, but it needs more than $24 \mathrm{~h}$ of incubation time to evidence this effect on cell proliferation. At the same concentration on human HTB-126 cells, K:D-Rib solution shows a clear replication slowing but the cytostatic effect at $10 \mathrm{mM} \mathrm{K:D-Rib}$ solution only. Results on A72 cells indicate the $\mathrm{K}^{+}$uptake could be determinant either to arrest or to slow down cell growth.
\end{abstract}

Keywords: A72 canine cancer cell line, HTB-126 human cancer cell line, potassium bicarbonate, D-ribose, MTT assay, cancer, cell proliferation

\section{Introduction}

Cancer is still one of the major causes of death despite many years of study and many different research approaches. The theory of Cone [2] proposes that sustained depolarization of cell membrane is involved in the regulation and control of cell division during both normal and cancerous growth of tissues. Using X-Ray microanalytic method [3] the correlation between the high $\mathrm{Na}^{+}$

\footnotetext{
* Correspondence: simonetta.croci@unipr.it

'Dipartimento di Sanità Pubblica, Sezione di Fisica, University of Parma Via Volturno 39, Parma, Italy

Full list of author information is available at the end of the article
}

content and the proliferative cell capacity has been proved in different cell types $[4,5]$. The scope of the present work is to assess the effects of potassium hydrogen carbonate and D-ribose water solution (K:D-Rib) on A72 canine and HTB-126 human cancer cell proliferation. Our previous study [6] showed the strong antioxidant effect of potassium ascorbate (KAsc) on red blood cell oxidation $[7,8]$. That work [6] focused on potassium ascorbate which seems to act as a carrier of $\mathrm{K}^{+}$inside the cells equilibrating the $\mathrm{K}^{+}$inner concentration. Potassium is essential for cell life and it is involved in many different cell pathways. Under physiological condition, $\mathrm{K}^{+}$has

\section{Biomed Central}

(c) 2011 Croci et al; licensee BioMed Central Ltd. This is an Open Access article distributed under the terms of the Creative Commons Attribution License (http://creativecommons.org/licenses/by/2.0), which permits unrestricted use, distribution, and reproduction in any medium, provided the original work is properly cited. 
intracellular concentration of about $150 \mathrm{mM}$ and an extracellular concentration of about $5 \mathrm{mM}$. Intracellular homeostasis for $\mathrm{Na}^{+}$and $\mathrm{K}^{+}$is no longer tightly regulated in cancer cells. An alteration of $\mathrm{Na}^{+} / \mathrm{K}^{+}$ATPase expression and activity has been shown in patients with cancer $[9,10]$. Epidemiologic evidence suggests that a high $\mathrm{K}^{+}$ intake inhibits cancer development, and a high $\mathrm{Na}^{+}$ intake increases the incidence of gastrointestinal malignancies. Studies in human epithelial-derived malignancies indicate that $\mathrm{K}^{+}$depletion also occurs, contributing to the increased intracellular $\mathrm{Na}^{+} / \mathrm{K}^{+}$ratio $[1] . \mathrm{Na}^{+} / \mathrm{K}^{+}$ ATPase uses energy from the hydrolysis of ATP to drive $\mathrm{K}^{+}$into cells in exchange for $\mathrm{Na}^{+}$, which in turn, provides the driving force for the transport of other solutes, notably amino acids, sugars, and phosphates [10]. It has been found that $\mathrm{K}^{+}$is essential to fold and to stabilize G-quadruplex [11]. Agents that stabilize G-quadruplexes can act as anti-tumour agents, so physiological $\mathrm{K}^{+}$concentration is responsible for normal cell behaviour $[12,13]$. Despite these findings, many questions on the key role of $\mathrm{K}^{+}$are still not completely clarified, in fact $\mathrm{K}^{+}$has a significant role also on apoptotic events [14].

D-ribose, is a penta-sugar precursor of some amino acids like glutamate, histidine, proline and arginine. Dribose transformed to piruvate, enters into the Krebs's cycle and has a key role on energetic metabolism; it is also involved in glycogen synthesis. The up-regulation of glycolysis in tumour cells is already well known and it is the rationale of $\mathrm{F}^{18}$-FDG PET diagnostic technique [15]. Glucose could be used for energy production through glycolysis, energy storage through glycogen synthesis and for intracellular process through the pentose phosphate pathways (PPP) [3]. Constitutive up-regulation of glycolysis is also observed even in the presence of adequate oxygen supplies (aerobic glycolysis): a phenomenon first noted by Warburg effect [16]. D-ribose can be directly synthesized by the non-oxidative transketolase PPP reaction transferring a keto group to glyceraldeyde 3-phoshate from fructose 6-phosphate. Both these substrates are intermediate products of glycolysis.

Because of all this evidence, we started testing the effect of K:D-Rib on A72 cell line proliferation at different concentrations: $5 \mathrm{mM}, 0.5 \mathrm{mM}$, and $0.05 \mathrm{mM}$. The cell growth is evaluated using $\mathrm{MCDI}^{\mathrm{TM}}$ software. We move on testing K:D-Rib solution on HTB-126 human cancer cell line. The effect of $5 \mathrm{mM} \mathrm{K}$ :D-Rib solution on proliferation and replication capability was valuated with clonogenic assay and counting the number of splitting during 48 days. Preliminary experiments are reported showing the interaction between K:D-Rib and 3-[4,5- dimethylthiazolyl-2]-2,5-diphenyltetrazolium bromide (MTT), which is commonly used to test the cell proliferation and viability.

\section{Results}

The MTT proliferation assay was performed testing the $\mathrm{K}$ :D-Rib concentrations from $0.15 \mathrm{mM}$ to $150 \mathrm{mM}$, according to methods. Absorbance data at $540 \mathrm{~nm}$ with respect to $690 \mathrm{~nm}$ are reported in Figure 1. Values at $0.15 \mathrm{mM}$ and $1.5 \mathrm{mM} \mathrm{K}$ :D-Rib concentrations indicate no significant differences between control and treated cells.

At higher K:D-Rib concentrations $(75 \mathrm{mM}$ and 150 $\mathrm{mM}$ ) absorbance soars in the treated samples with respect to the control, both at $24 \mathrm{~h}$ and $48 \mathrm{~h}$.

On the other hand, the pictures taken with the digital microscope camera display fewer cell in the $75 \mathrm{mM}$ sample at $24 \mathrm{~h}$ as shown in Figure 2. In this case cells exhibit morphological damages and they are no more viable, both at $48 \mathrm{~h}$ (75 mM K:D-Rib) and at $24 \mathrm{~h}$ (150 mM K: D-Rib). It seems that at these K:D-Rib concentrations the MTT salt interacts with the K:D-Rib solution.

To this purpose we analyzed the UV/VIS absorption spectrum to highlight the products of a MTT - K:D-Rib reaction. Samples with MTT salt were prepared, according to methods, with different $\mathrm{K}: \mathrm{D}-\mathrm{Rib}$ concentrations: $150 \mathrm{mM}$ (S150), $75 \mathrm{mM}$ (S75), $15 \mathrm{mM}$ (S15), $10 \mathrm{mM}$ (S10) $5 \mathrm{mM}$ (S5) and $1.5 \mathrm{mM}$ (S1.5). The S150 sample did not show a good solubilization and some crystals were present in the solution, therefore we thought the UV/VIS spectrum for this sample had to be discarded. The spectrum of a MTT solution with SDS is also reported in Figure 3A (dashed line). Because the MTT salt was not completely reduced by K:D-Rib solution, to obtain MTT - K:D-Rib interaction product spectrum we cleaned the raw spectra by subtracting the MTT-SDS

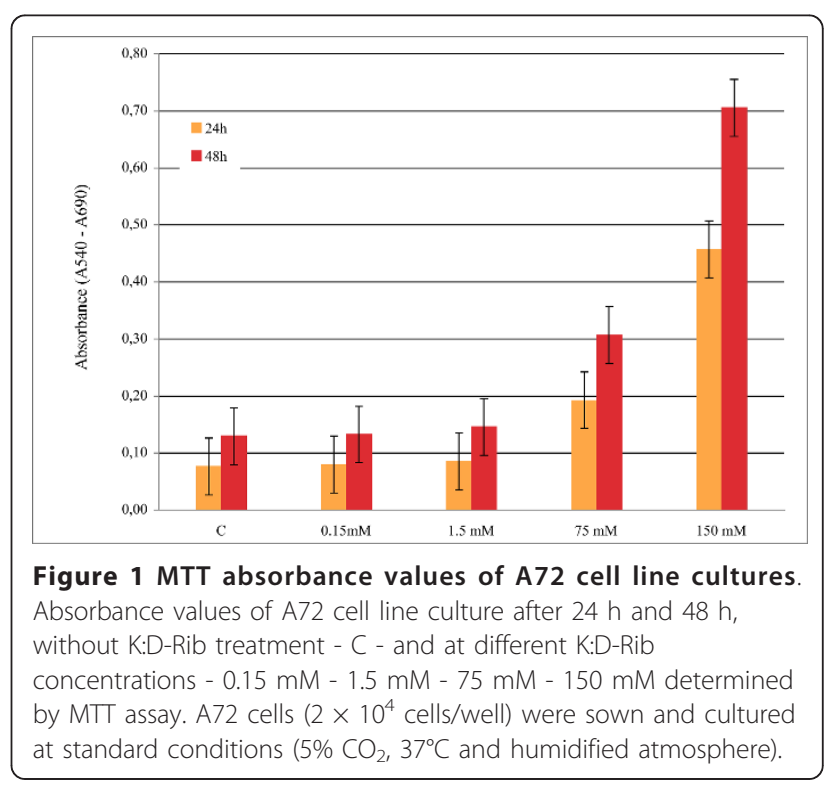




\section{$24 \mathrm{~h}$}
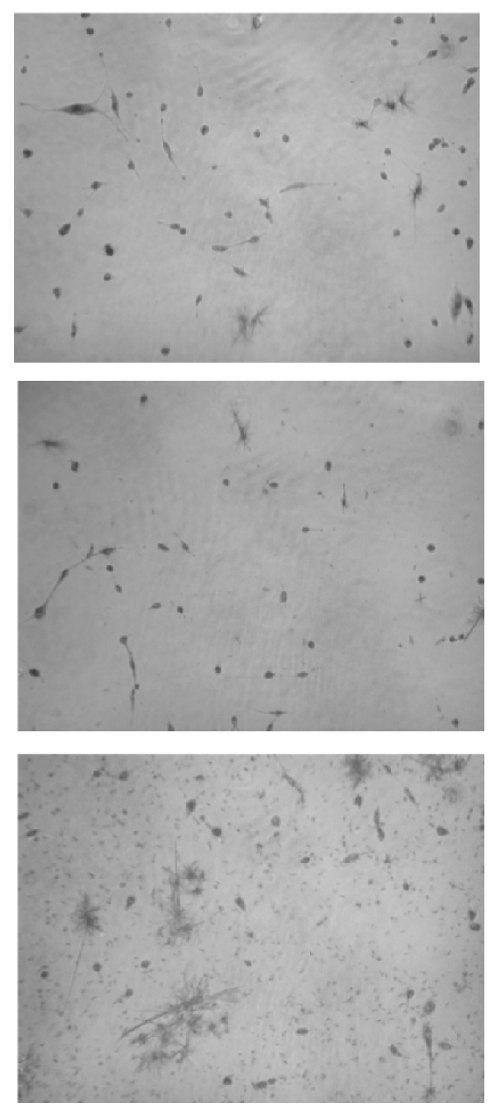

$48 \mathrm{~h}$

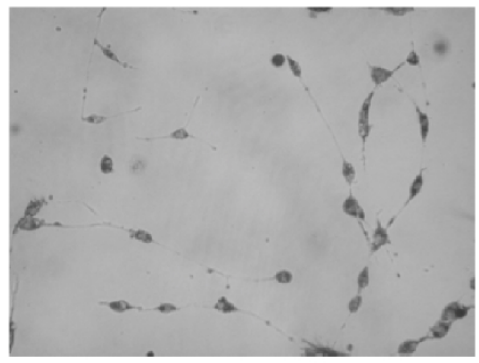

Control

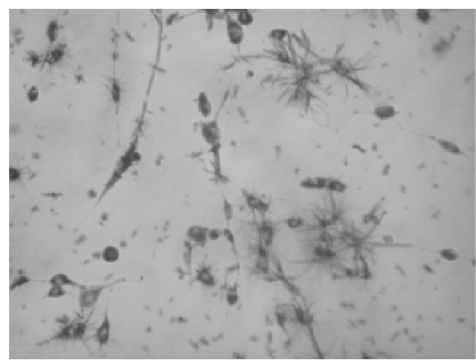

$75 \mathrm{mM}$

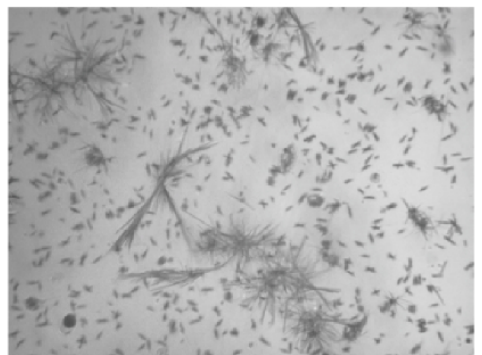

\section{$150 \mathrm{mM}$}

Figure 2 Microscope images of A72 cells with MTT salt. A72 cell images: control, 75 mM K:D-Rib and 150 mM K:D-Rib after 24 h and 48 h of incubation. The pictures were taken just after the MTT assay measurements whose absorbance values, at $75 \mathrm{mM}$ and at $150 \mathrm{mM}$ K:D-Rib concentrations are reported in Figure 1.

solution spectrum from the S75, S15, S10, S5 and S1.5 spectra, being the K:D-Rib solution absorption neglible between $400 \mathrm{~nm}$ and $720 \mathrm{~nm}$.

In the inset of Figure 3A, $75 \mathrm{mM}$ K:D-Rib sample spectrum is shown. Figure 3B displays the spectra of MTT salt and of formazan after solubilization as shown by ROCHE data sheet of Cell Proliferation Kit I (MTT). Comparing the formazan spectrum of Figure 3B (dashed line) with spectra of Figure 3A (solid lines) it is clear that K:D-Rib interacts with MTT producing formazan salt. It is also evident that the amount of formazan is proportional to K:D-Rib concentration.

Because all this evidence, the cell proliferation and morphology were then evaluated by means of the digital photos analysed with $\mathrm{MCID}^{\mathrm{TM}}$ program. The treated cells, incubated with $5 \mathrm{mM}, 0.5 \mathrm{mM}$ and $0.05 \mathrm{mM} \mathrm{K}$ :DRib were then fixed and stained, as stated in methods. The effects were evaluated after $24 \mathrm{~h}, 48 \mathrm{~h}$ and $72 \mathrm{~h}$ from sowing. To prove accuracy of the analysis we define in each stained plate six different regions and we took separate pictures of all of them. Using the MCID ${ }^{\mathrm{TM}}$ program one is able to identify the stained nucleus and therefore to count the number of cells in each picture. An example of one region for each cell plate is presented in Figure 4.

Every picture was analysed by MCDI ${ }^{\mathrm{TM}}$ software and the overall count of a plate was computed averaging together the results for the six different pictures of a plate. The data reported in Figure 5 are the cell number averages of the six pictures of a given cell plate. The graph relates the cell number with concentration and incubation time. It is clear that cells treated with 0.05 $\mathrm{mM}, 0.5 \mathrm{mM}$ and $5 \mathrm{mM} \mathrm{K}$ :D-Rib grow faster than control both after $24 \mathrm{~h}$ and after $48 \mathrm{~h}$, but a different kinetic shows up after $72 \mathrm{~h}$. At $0.05 \mathrm{mM}$ K:D-Rib concentration after $48 \mathrm{~h}$ from sowing the cell number is three times higher than control. There is no significant growth between $48 \mathrm{~h}$ and $72 \mathrm{~h}$. Conversely the $0.5 \mathrm{mM} \mathrm{K}$ :D-Rib 

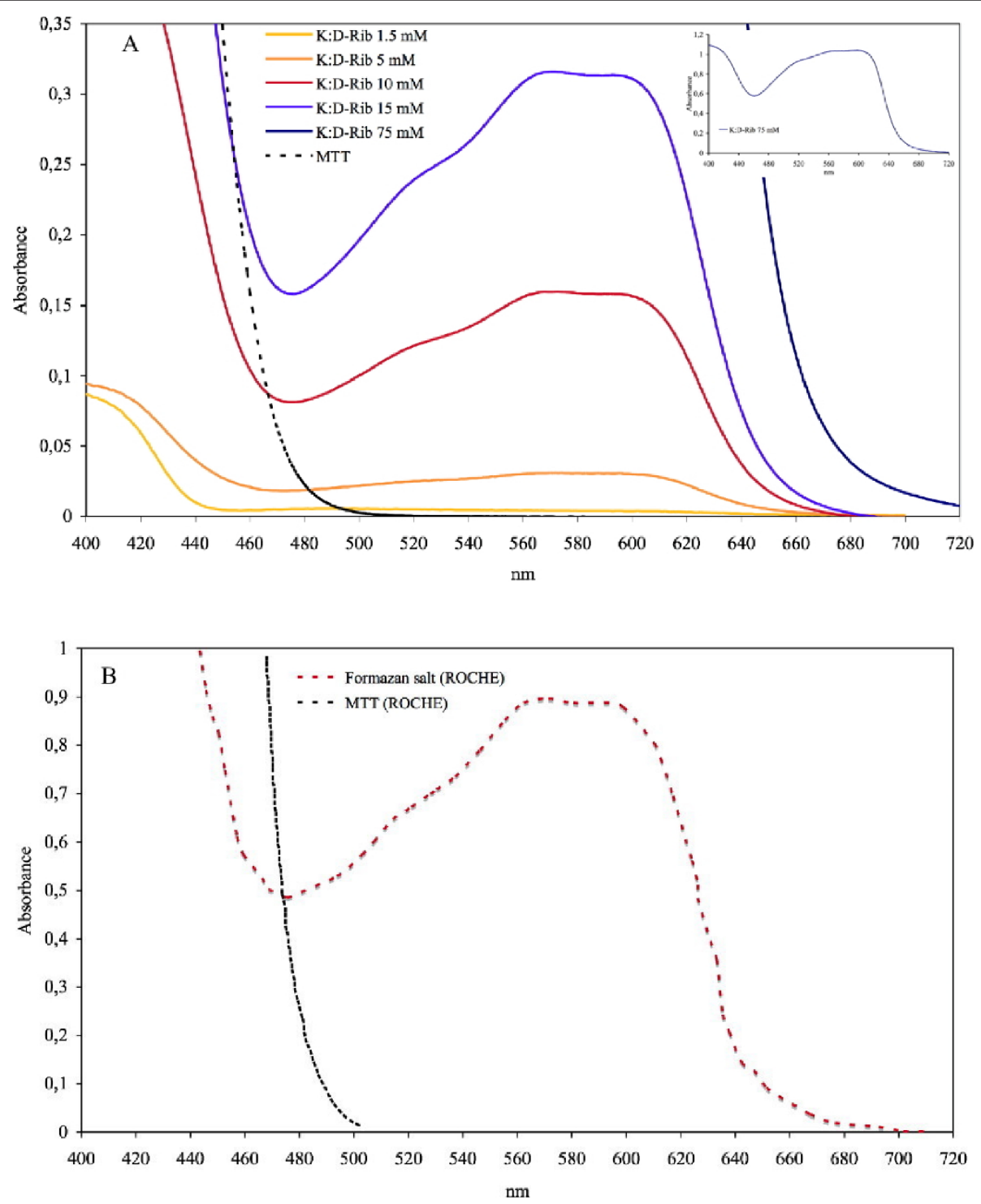

Figure 3 UV/VIS absorbance spectra of MTT salt with and without K:D-Rib solution. A, black dashed line: MTT - SDS UV/VIS spectrum; coloured solid lines: MTT - K:D-Rib interaction product UVNIS spectra after solubilization obtained subtracting the MTT- SDS spectrum from raw data. Different K:D-Rib concentrations, 1.5 mM, 5 mM, 10 mM, 15 mM and 75 mM (inset) were used. B, black line: MTT salt UVNIS spectrum; red line: formazan salt after solubilization (ROCHE data sheet).

concentration has a completely different effect: cells grow markedly slower than cells treated with $0.05 \mathrm{mM} \mathrm{K}: \mathrm{D}-\mathrm{Rib}$ both at $48 \mathrm{~h}$ and $72 \mathrm{~h}$. At $5 \mathrm{mM}$ (highest K:D-Rib concentration tested on A72) the cell number after $48 \mathrm{~h}$ is around the same with respect to the control after $72 \mathrm{~h}$. In the case of $5 \mathrm{mM} \mathrm{K:D-Rib} \mathrm{treated} \mathrm{cells,} \mathrm{growth} \mathrm{arrests}$ between $48 \mathrm{~h}$ and $72 \mathrm{~h}$. Due to the previous results, the 5 mM K:D-Rib concentration was also tested on HTB-126 human cancer cells.

In order to assess the effect of $5 \mathrm{mM} \mathrm{K}$ :D-Rib on cell proliferation we carried out a growth rate estimation by observing our sown cells over a 48 day period of time.
When the sown cells reached the $90 \%-100 \%$ confluence, they were split 1:2. After 48 days control was split 16 times while the $5 \mathrm{mM} \mathrm{K}$ :D-Rib treated cells 11 times.

To test the cell capability to survive and replicate following the incubation with $5 \mathrm{mM}$ and $10 \mathrm{mM} \mathrm{K}$ :D-Rib solution, clonogenic assay was performed. A colony is defined as a cluster of at least 50 cells. We count nine colonies in the control sample as is shown in Figure 6A. In Figure 6C the picture of a representative colony of the control sample is reported. In the case of the $5 \mathrm{mM} \mathrm{K}$ :D-Rib treated cells, only one colony is formed as reported in Figure 6B and $6 \mathrm{D}$, but at $10 \mathrm{mM} \mathrm{K}: \mathrm{D}-\mathrm{Rib}$ there was no colony. 


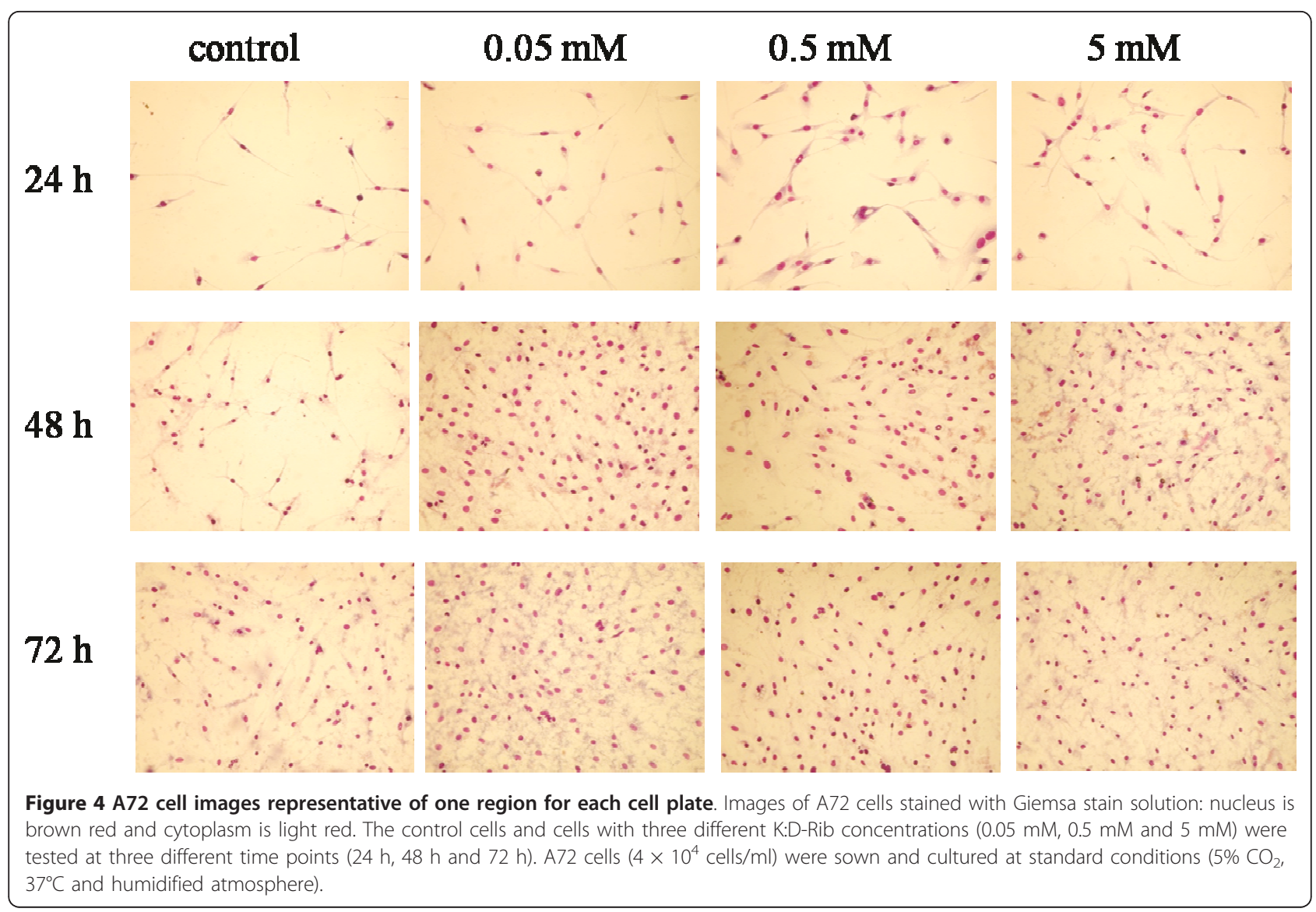

\section{Discussion and conclusions}

The MTT assay data at high K:D-Rib concentrations, $75 \mathrm{mM}$ and $150 \mathrm{mM}$, suggest an enhancement of the cell proliferation. According to these absorbance values, cells should be viable and proliferative at any K:D-Rib concentration. But as one can see from the results shown in Figure 2, the previous conclusions clash with the observation of the morphological damages brought about the treated cells. These results are not so surprising, in fact the samples with $75 \mathrm{mM}$ and $150 \mathrm{mM} \mathrm{K:D-Rib}$ solutions have a $\mathrm{K}^{+}$concentration which is between forty and ninety times higher than physiological extracellular concentration $(5 \mathrm{mM})$. The cell death could be a consequence of the culture medium osmolality. What actually is more surprising is the non-reliability of the MTT test. These results, together with results obtained from UV/VIS spectroscopy, prove the interaction of MTT with the K:D-Rib solution with the following consequences. The K:D-Rib solution reduces MTT salt to formazan with a behaviour similar to ascorbic acid behaviour. Spontaneously the ascorbic acid reduces MTT salt to a formazan as it reduces many compounds such as $\mathrm{H}_{2} \mathrm{O}_{2}$ and cytochrom $c$ [17]. This antioxidant behaviour of $\mathrm{K}: \mathrm{D}$-Ribose solution is evident also at low concentrations of about $5 \mathrm{mM}$. Because the absorbance results of the MTT assay provide erroneous information about cell viability, the cells were then stained and counted with help of the MCID ${ }^{\mathrm{TM}}$ program. K:D-Rib solution has two important components D-ribose and potassium, actually the $\mathrm{K}^{+}$source is the potassium hydrogen carbonate. As is shown in Figure 5, the cell population of all this treated plates is not significantly different after $24 \mathrm{~h}$ of incubation time but it is higher than control. One can deduce that D-ribose enters into the cell [18] and it is metabolized as carbon source increasing cell growth and consequently the cell number. Highest growth enhancement occurs at $0.05 \mathrm{mM} \mathrm{K}: \mathrm{D}-\mathrm{Rib}$ between $24 \mathrm{~h}$ and $48 \mathrm{~h}$. In this case, the $\mathrm{K}^{+}$concentration is $0.15 \mathrm{mM}$, thirty times lower than the extracellular concentration $(\sim 5 \mathrm{mM})$, not enough to change any ion balance, thus the population increase has to be attributed to D-ribose sugar. $\mathrm{K}^{+}$may tend to rebalance its intracellular concentration and reestablish the normal cellular functions, but only the effect of D-ribose is evident at low $\mathrm{K}^{+}$intracellular concentration. At $0.5 \mathrm{mM} \mathrm{K:D-Rib}$, the cell growth is slowed down with respect to the $0.05 \mathrm{mM} \mathrm{K}$ :D-Rib treated cells, but at this concentration there is no cell growth stop. In this case, in accordance with the previous interpretation, the $\mathrm{K}^{+}$begins to show its effect, but it is not enough to stop 


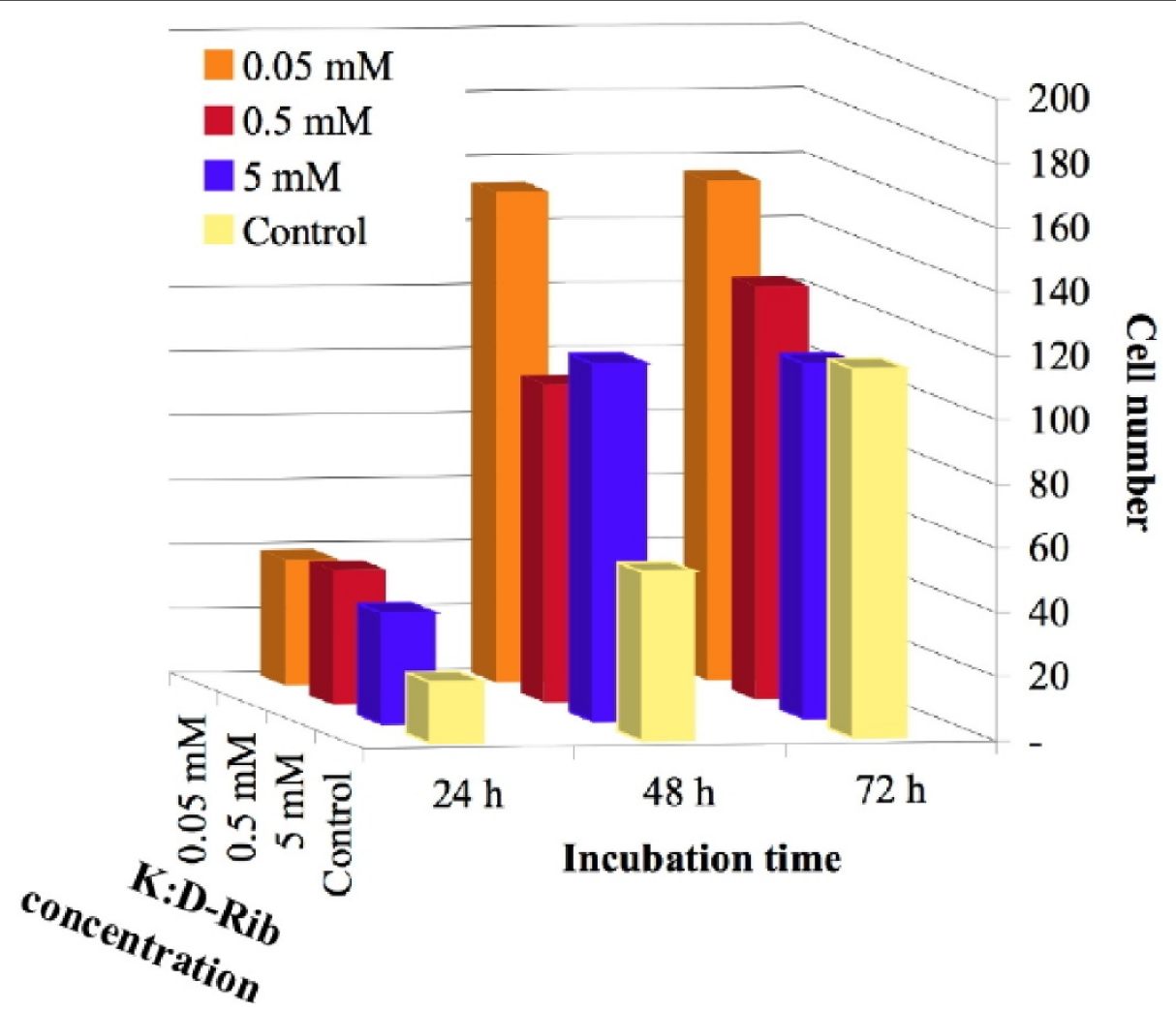

Figure 5 Cell number at different incubation time and at different K:D-Rib concentrations. Bars are the cell number averages of the six pictures of a given cell plate. Bars are relative to control cells and to K:D-Rib treated cells $(0.05 \mathrm{mM}, 0.5 \mathrm{mM}, 5 \mathrm{mM})$ at three different time points ( $24 \mathrm{~h}, 48 \mathrm{~h}$ and $72 \mathrm{~h}$ ).

the increase of cell population. Indeed, at $5 \mathrm{mM}$ K:D-Rib concentration, the solution has a cytostatic effect. Cell growth slows down with respect to $0.05 \mathrm{mM}$ after $48 \mathrm{~h}$ and to the $0.5 \mathrm{mM}$. In addition they stop their growth between $48 \mathrm{~h}$ and $72 \mathrm{~h}$ from sowing.

Firstly from UV/VIS results, we can conclude that the K:D-Rib has a antioxidant behaviour also at concentration of about $5 \mathrm{mM}$. On A72 cancer cells K:D-Rib, at any tested concentration, needs more than $24 \mathrm{~h}$ of incubation time to show effects on cell proliferation, but at $5 \mathrm{mM}$ it shows a cytostatic effect. $\mathrm{K}^{+}$uptake seems to be determinant either to arrest or to slow down cell growth. This effect at $5 \mathrm{mM}$ cannot be attributed to an osmolality effect since the $\mathrm{K}^{+}$concentration is of same order of magnitude of the physiological concentration. At 0.05 $\mathrm{mM}$ K:D-Rib concentration the $\mathrm{K}^{+}$concentration is thirty times lower than physiological extra cellular one; only the effect of D-ribose is visible, and cell are growing. Starting with higher $\mathrm{K}^{+}$concentration we see a marked slow down in the cell growth. We suggest that D-ribose is acting as a "Trojan horse" that is carrying $\mathrm{K}^{+}$inside the cells. These preliminary results are of fundamental importance and they have been the starting point for studying the K:D-Rib solution effect on human cancer cells. Because we had the most relevant results with 5 mM K:D-Rib concentration, we started with the same concentration on HTB-126 human breast cancer cells. As reported in the results section an established slowing of cell growth rate was demonstrated during 48 days treatment: the control cells were split every 2.7 days on average while the $5 \mathrm{mM} \mathrm{K}$ :D-Rib treated cells were split every 4 days on average, for a total of 16 and 11 times respectively. This result is confirmed by the clonogenic assay where nine colonies were formed in control with respect to only one in the $5 \mathrm{mM} \mathrm{K}$ :D-Rib treated sample. These results on a human breast cancer cell line at $5 \mathrm{mM}$ K:DRib show a similar effect than on A72 cell line, in fact the cell replication is strongly reduced although not completely blocked. At this concentration we did not see cytostatic effect on HTB-126 cells but the cytostatic effect was evident at $10 \mathrm{mM} \mathrm{K}$ :D-Rib. Actually it is not surprising that different cell system have a different dose-effect response.

In the next step we will continue to test the K:D-Rib on human cancer cells and in the meanwhile we will try to have a better understanding on the cellular mechanisms that are involved in this cytostatic behaviour focusing on $\mathrm{K}^{+}$and D-ribose role. 


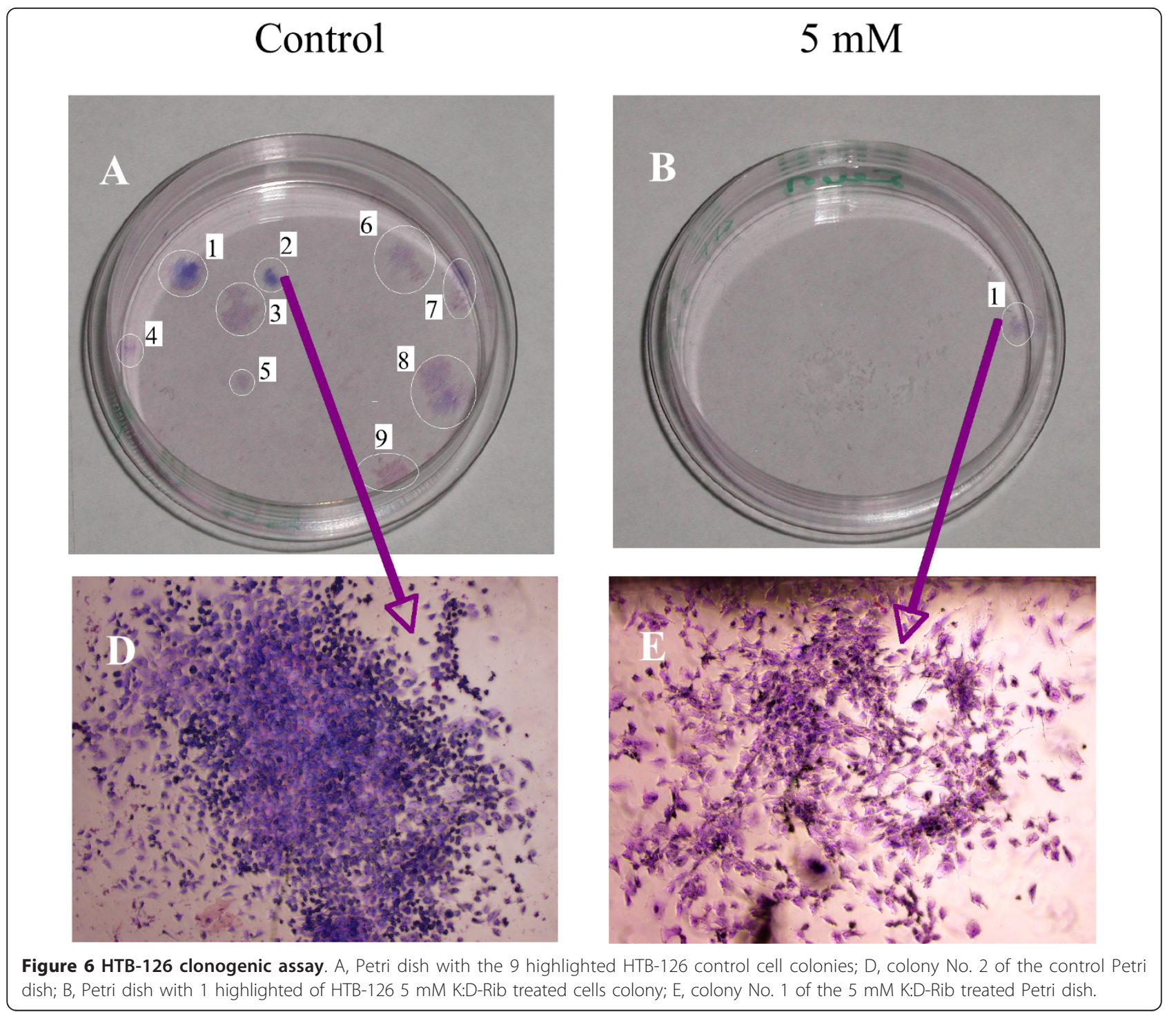

Finally we also suggest a careful use of MTT assay test when the interactions between cells with other system are tested $[19,20]$.

\section{Methods}

\section{Cells and culture conditions}

A72 adherent canine tumour cell line was obtained from American Type Culture Collection (Manassas, VA, USA). A72 cells were maintained in high glucose Dulbecco's Modified Eagle's Medium (Sigma Aldrich) supplemented by: 10\% Fetal Calf Serum (Sigma Aldrich) and 1\% L-Glutamine (Sigma Aldrich), 1\% Penicillin-Streptomycin (Sigma Aldrich). A72 cell line was incubated at $37^{\circ} \mathrm{C}$ in humidified atmosphere with $5 \% \mathrm{CO}_{2}$.

HTB-126 adherent human breast cancer cell line was obtained from American Type Culture Collection (Manassas, VA, USA). HTB-126 cells were maintained in low glucose Dulbecco's Modified Eagle's Medium (Lonza) supplemented by: 10\% Fetal Calf Serum (Lonza), 1\% LGlutamine (Lonza), and 1\% Penicillin-Streptomycin (Lonza). HTB-126 cell line was incubated at $37^{\circ} \mathrm{C}$ in humidified atmosphere with $5 \% \mathrm{CO}_{2}$.

\section{Chemicals}

Giemsa stain modified solution was bought from Fluka. MTT yellow salt (3-[4,5-dimethylthiazolyl-2]-2,5-diphenyltetrazolium bromide), paraformaldehyde powder and sodium dodecilsulfate (SDS) were purchased from Sigma Aldrich. $\mathrm{HCl}$ was bought from MERCK.

\section{Drugs}

D-ribose was bought from Sigma-Aldrich and potassium hydrogen carbonate from BDH. 1 M K:D-Rib solution is obtained by combining $0.15 \mathrm{~g}$ of D-ribose and $0.3 \mathrm{~g}$ of 
potassium hydrogen carbonate in distilled water; then waiting for the $\mathrm{CO}_{2}$ to dissipate. The concentrations desired were reached diluting the stock solution with distilled water.

\section{MTT proliferation assay}

The MTT assay was employed to valuate the K:D-Rib effects on cell proliferation and viability. The K:D-Rib tested concentrations were: $0.15 \mathrm{mM}, 1.5 \mathrm{mM}, 75 \mathrm{mM}$ and $150 \mathrm{mM}$. A72 cell line was sown at 1000 cells/100 $\mu \mathrm{l}$ concentration into a 96-well plate. MTT salt is reduced to formazan in the metabolic active cells by dehydrogenase to form NADH and NADPH. The cell reduction product, called formazan displays a purple colour. It can be quantified spectroscopically after solubilization. From each well, $100 \mu \mathrm{l}$ of surnatant were discarded. Then $20 \mu \mathrm{l}$ of MTT (reconstituted powder in PBS $1 \mathrm{X}$ at $5 \mathrm{mg} / \mathrm{ml}$ ) were added to each well. The cells with MTT solution were incubated for $4 \mathrm{~h}$ at $37^{\circ} \mathrm{C}$. Then $100 \mu \mathrm{l}$ of solubilization buffer (SDS $10 \%$ in HCL $0.01 \mathrm{~N}$ ) were added to the cells and they were incubated at $37^{\circ} \mathrm{C}$ overnight. At the end of this incubation time, the assayed plates were read by Spectra Shell microplate reader, at the wavelength of $540 \mathrm{~nm}$ respects to $690 \mathrm{~nm}$. The absorbance was measured at $24 \mathrm{~h}$ and $48 \mathrm{~h}$ after sowing. Absorbance is proportional to the number of viable cells.

\section{Optical measurements}

A UV/VIS Varian spectrometer was used from $400 \mathrm{~nm}$ to $720 \mathrm{~nm}$ to follow the MTT salt reaction with K:D-Rib solution. In case of K:D-Rib the tested concentrations were: $150 \mathrm{mM}, 75 \mathrm{mM}, 15 \mathrm{mM}, 10 \mathrm{mM}, 5 \mathrm{mM}, 1.5 \mathrm{mM}$. $200 \mu \mathrm{l}$ of MTT solution were added in $2 \mathrm{ml} \mathrm{K:D-Rib} \mathrm{solu-}$ tion. The samples were measured, similarly to the procedure done with the cells, after an incubation time of $4 \mathrm{~h}$ at $37^{\circ} \mathrm{C}$, followed by the addition of $2 \mathrm{ml}$ of solubilization solution (sodium dodecilsulfate SDS 10\%) left overnight.

\section{Microscope cell counting}

The tested K:D-Rib concentrations were: $0.05 \mathrm{mM}$, $0.5 \mathrm{mM}$ and $5 \mathrm{mM}$. The counts were performed at $24 \mathrm{~h}$, $48 \mathrm{~h}$ and $72 \mathrm{~h}$ from sowing. $40000 \mathrm{cells} / \mathrm{ml}$ were sown into a 4-well plate. The cells were fixed at air flux of the biological cape, at every time point for one hour. After that, the cells were stained by Giemsa stain solution and photographed by microscope digital camera. Cell counting was done analyzing the cell images with $\mathrm{MCID}^{\mathrm{TM}}$ software.

\section{Splitting number}

The tested K:D-Rib concentration was $5 \mathrm{mM}$. HTB-126 cell line was sown at 10000 cells/ml into $35 \mathrm{~mm}$ Petri dish. When the cells were approximately $90-100 \%$ confluent they were split 1:2. This procedure continued for
48 days. The splitting number is reported both for control cells and for $5 \mathrm{mM} \mathrm{K:D-Rib} \mathrm{treated} \mathrm{cells.}$

\section{Clonogenic assay}

$24 \mathrm{~h}$ before treatment, HTB-126 cells were sown at the concentration of 25 cells $/ \mathrm{ml}$ in a $35 \mathrm{~mm}$ Petri dish, waiting for the cells adhesion. The tested K:D-Rib concentrations were $5 \mathrm{mM}$ and $10 \mathrm{mM}$; the treatment lasted for tree weeks. The cell medium was changed once a week. After tree weeks colonies were fixed with paraformaldehyde $(4.0 \% \mathrm{v} / \mathrm{v})$, stained with Giemsa solution $(5.0 \% \mathrm{v} / \mathrm{v})$ and counted using an inverted microscope. A colony is defined to consist of at least 50 cells.

\section{Acknowledgements}

This investigation was supported by the Valsè Pantellini Foundation and Fondazione Cariparma. We give hearty thank to Prof. I. Ortalli for many helpful discussions and suggestions, Prof. S. Bettati for help in performing the UVNIS measurements and Prof. Massimo Manghi for the careful text revision and discussion.

\section{Author details}

${ }^{1}$ Dipartimento di Sanità Pubblica, Sezione di Fisica, University of Parma Via Volturno 39, Parma, Italy. ${ }^{2}$ INBB (Istituto Nazionale Biostrutture e Biosistemi) Via delle medaglie d'Oro 305, Roma, Italy. ${ }^{3}$ Valsè Pantellini Foundation, Calle Cervantes, 16/4 izda, Oviedo Asturia, Spain. ${ }^{4}$ Dipartimento di Produzioni Animali, Biotecnologie Veterinarie, Qualità e Sicurezza degli Alimenti-Sezione di Fisiologia Veterinaria, University of Parma, Via del taglio 10, Parma, Italy. ${ }^{5}$ Dipartimento di Salute Animale, Sezione di Clinica Medica Veterinaria, University of Parma, Via del taglio 10, Parma, Italy.

Received: 24 February 2011 Accepted: 22 August 2011

Published: 22 August 2011

\section{References}

1. Davis RJ, Daly JM: Potassium depletion and malignant transformation of villous adenomas of the colon and rectum. Cancer 1984, 53:1260-1264.

2. Cone CD: Unified theory on basic mechanism of normal mitotic control and oncogenesis. Journal of Theoretical Biology 1971, 30(1):151-181.

3. Boros LG, Lee PWN, Brandes JL, Cascante M, Muscarella P, Schirmer WJ, Melvin WS, Ellison EC: Nonoxidative pentose phosphate pathways and their direct role in ribose synthesis in tumors: is cancer a disease of cellular glucose metabolism? Medical Hypotheses 1998, 50(1):55-59.

4. Smith NKR, Stabler SB, Cameron IL, Medina D: X-Ray-Microanalysis of Electrolyte Content of Normal, Preneoplastic, and Neoplastic Mouse Mammary Tissue. Cancer Research 1981, 41(10):3877-3880.

5. Arrebola F, Fernandez-Segura E, Campos A, Crespo PV, Skepper JN, Warley $A$ : Changes in intracellular electrolyte concentrations during apoptosis induced by UV irradiation of human myeloblastic cells. American Journal of Physiology-Cell Physiology 2006, 290(2):C638-C649.

6. Croci S, Pedrazzi G, Paoli G, Monetti D, Ortalli I: Potassium ascorbate as protective agent in the oxidation of the red blood cells. Hyperfine Interactions (C), Vol 5, Proceedings 2002, 241-244.

7. Croci S, Pedrazzi G, Passeri G, Delsignore R, Ortalli I: Red cell Hb oxidation of healthy subjects compared to breast cancer patients. Anticancer Research 2002, 22(5):2903-2906.

8. Croci S, Pedrazzi G, Passeri G, Piccolo P, Ortalli l: Acetylphenylhydrazine induced haemoglobin oxidation in erythrocytes studied by Mossbauer spectroscopy. Biochimica Et Biophysica Acta-General Subjects 2001, 1568(1):99-104.

9. Mobasheri A, Fox R, Evans I, Cullingham F, Martín-Vasallo P, Foster C: Epithelial $\mathrm{Na}$, K-ATPase expression is down-regulated in canine prostate cancer; a possible consequence of metabolic transformation in the process of prostate malignancy. Cancer Cell International 2003, 3(1):8. 
10. Chen JQ, Contreras RG, Wang R, Fernandez SV, Shoshani L, Russo $\mathbb{H}$, Cereijido M, Russo J: Sodium/potasium ATPase (Na+, K+-ATPase) and ouabain/related cardiac glycosides: a new paradigm for development of anti-breast cancer drugs? Breast Cancer Research and Treatment 2006, 96(1):1-15.

11. Parkinson GN, Lee MPH, Neidle S: Crystal structure of parallel quadruplexes from human telomeric DNA. Nature 2002, 417(6891):876-880.

12. Dai JX, Carver M, Yang DZ: Polymorphism of human telomeric quadruplex structures. Biochimie 2008, 90(8):1172-1183.

13. Kelland LR: Overcoming the immortality of tumour cells by telomere and telomerase based cancer therapeutics - current status and future prospects. European Journal of Cancer 2005, 41(7):971-979.

14. Hughes FM, Bortner CD, Purdy GD, Cidlowski JA: Intracellular K+ suppresses the activation of apoptosis in lymphocytes. Journal of Biological Chemistry 1997, 272(48):30567-30576.

15. Gillies RJ, Robey I, Gatenby RA: Causes and consequences of increased glucose metabolism of cancers. Journal of Nuclear Medicine 2008, 49:24S-42S.

16. Warburg O: Ueber den stoffwechsel der tumoren. London UK: Constable 1930.

17. Chakrabarti R, Kundu S, Kumar S, Chakrabarti R: Vitamin A as an enzyme that catalyzes the reduction of MTT to formazan by vitamin c. Journal of Cellular Biochemistry 2000, 80(1):133-138.

18. Fehr M, Okumoto S, Deuschle K, Lager I, Looger LL, Persson J, Kozhukh L, Lalonde S, Frommer WB: Development and use of fluorescent nanosensors for metabolite imaging in living cells. Biochemical Society Transactions 2005, 33:287-290.

19. Belyanskaya $L$, Manser $P$, Spohn $P$, Bruinink A, Wick P: The reliability and limits of the MTT reduction assay for carbon nanotubes-cell interaction. Carbon 2007, 45(13):2643-2648.

20. Plumb JA, Milroy R, Kaye SB: Effects of the pH-dependence of 3-(4,5dimethylthiazol-2-yl)-2,5-diphenyl-tetrazolium bromide-formazan absorption on chemosensitivity determined by a novel tetrazoliumbased assay. Cancer Research 1989, 49(16):4435-4440.

doi:10.1186/1475-2867-11-30

Cite this article as: Croci et al:: Potassium bicarbonate and D-ribose effects on A72 canine and HTB-126 human cancer cell line proliferation in vitro. Cancer Cell International 2011 11:30.

\section{Submit your next manuscript to BioMed Central and take full advantage of:}

- Convenient online submission

- Thorough peer review

- No space constraints or color figure charges

- Immediate publication on acceptance

- Inclusion in PubMed, CAS, Scopus and Google Scholar

- Research which is freely available for redistribution

Submit your manuscript at www.biomedcentral.com/submit
C Biomed Central 